Original scientific article

UDC: $616-003.6 / .7(498) " 16 / 17 "$

$615.279(498) " 16 / 17 "$

ID: 228297228

DOI 10.25106/AHM.2016.2410

\author{
Ana-Maria Gruia \\ National History Museum of Transylvania \\ Daicoviciu St. 2, Cluj-Napoca, Romania \\ E-mail: ana.gruia@gmail.com
}

\title{
BEZOAR USE IN EARLY MODERN TRANSYLVANIA
}

\begin{abstract}
The present paper examines, for the first time, the use of bezoars in Transylvania during the $17^{\text {th }}$ and $18^{\text {th }}$ centuries. The author employs both written sources (correspondence, pharmacy inventories, apothecary tariffs, and memoirs) and historical artifacts in order to reconstruct the place of bezoars in the era's Materia Medica, by comparison with Western Europe.
\end{abstract}

Key words: bezoars, antidotes, Early Modern History of Medicine, Materia Medica NonMeSH: alexipharmics, Transylvania

Despite their name, bezoar stones are not actually stones, but concretions formed around agglomerations of undigested matter (usually hair or fibers), encountered mostly in ruminants. They are the most famous and prized antidotes of the Early Modern period, traded and handled like precious stones, and surrounded by magic and legend. Their equally exotic name is derived from the Persian padzahrpad-expelling, zahr-poison, attesting to their initial and most enduring function. Like other antidotes, bezoars were administered as powder suspended in liquids, usually wine, or as an infusion, with such stones soaked in water or wine, though they were also worn as amulets and mounted in various containers.Although their animal origin was generally recognized by the 16th century, there were, nevertheless, many other legends about how they were formed, from different organs or excretions of different animals [1, p. 197-198].

Despite their popularity, especially among the rich and powerful, and acknowledging the scarce and conflicting data on their nature and origin, there were always voices doubting the general efficacy of these Eastern (and later American) curiosities, 
mainly based on failed cures. I shall subsequently analyze the availability, use, and decline in popularity of bezoars in Transylvania, by reference to their use in Western Europe during the Early Modern period.

Bezoar stones are still regarded with fascination and have retained their magical allure to modern eyes. Much of their recent popularity is due to their being mentioned in Harry Potter's adventures, as J.K. Rawlings was substantially inspired by the old history of pharmacy. Several pharmacy museums worldwide have capitalized on this renewed interest in bezoars by organizing temporary exhibitions and refreshing their displays of such items [2, p. 8-9].

\section{Bezoars in Western Europe}

Bezoars were introduced into Europe during the twelfth century, through contacts between the Spanish and the Moors. The calcium and phosphates they contain seem to have actually neutralized the effect of arsenic, the most often used poison of the time [1, p. 193]. It appears that their popularity was in fact embedded in the medieval and early modern paranoia over poison scandals, of which tasteless and odorless arsenic was the deadliest and most common [3, p. 37-39]. It was also believed that they were useful as emetics, against fever, pestilence, as a medicine of last resort, and as panacea. Their popularity grew steadily, reaching a peak around the middle of the 17th century in Europe (also influenced by the new discoveries and trade routes of early colonial times and by the inclusion of bezoars in popular medicine), when the presumed properties of the bezoars also became more numerous. It was believed that they enhanced the efficacy of any other ingredients they were compounded with [3, p. 37]. Venetian men went to the pharmacy each morning and drank a glass of bezoar water in order to prolong their life [4, p. 74]. Toward the end of the $18^{\text {th }}$ century, their popularity as medical items decreased sharply; the influence of numerous and dangerous counterfeits, some containing toxic substances such as mercury, may have been a factor in this [1, p. 204].

Bezoar stones were not only prized as medicine and antidotes, but also as amulets that protected against poison and brought good fortune [5, p. 88-89], hence the numerous examples of such items mounted in precious metals and stones, found in most of Europe's Kunstkammer [1, p. 198-199]. Besides their reputed apotropaic function, the wearing of bezoars was also a matter of prestige, since the display of such expensive stones indicated the wealth and connections of their owners. Several bezoars, mounted in precious containers, carved into cups themselves, or set on chains to be worn close to the skin or to be suspended and soaked in liquids to make infusions, were part of Emperor Rudolf II's collection [1, p. 202-203]. His cabinet of curiosities included numerous such items and the emperor's predilection for bezoar stones is known from several sources. His agents compiled a large collection of them for him from all over Europe and with them Rudolf II attempted to wardoff the plague of 1599 [6, p. 2012, footnotes 13 and 14]. Part of the emperor's collection ended up in the princely Kunstkammer of Vienna, which also acquired bezoar stones 
and other exotica during the Age of Discovery, through the family's possessions in Spain and Portugal [7, p. 41. Several mounted bezoars are illustrated in 1].

In the Early Modern period, published sources differentiate between Occidental bezoars(Lapis bezoaris occidentalis), extracted from camelids of the New World, and Oriental bezoars (Lapis bezoaris orientalis), harvested from goats, of the Orient [3, p. 31; 5, p. 82-86]. The Occidental specimens were first found in Peru around 1568 [8, p. 17]. The great majority of oriental bezoars were obtained from goats, though such "stones" collected from porcupines, hogs, and monkeys were more expensive. Larger stones were deemed to be of better quality and greater efficacy, and were thus even more expensive than the others, worth up to ten times their weight in gold [1, p. 196]. Forging bezoars was a very profitable business, though dangerous to the patients. Artificial bezoars were probably fabricated by pharmacists from the cheaper powder of smaller stones, or the so-called Goa Stone that was a mix of various ingredients which included bezoar powder [3, p. 40].

\section{Bezoars in Transylvania}

Though several recent studies have turned to the history, use, and commerce in bezoars in Europe during the Late Medieval and Early Modern period, little is known about if, how, and by whom they were used in Transylvania. I have been able to find several mentions of bezoars in the Materia Medica of Transylvania during the 17th and 18 th centuries and one knows that they were kept in official apothecary use there until the beginning of the nineteenth century [9, p.192]. There are also a couple of relevant artifacts preserved in the History of Pharmacy Collection in Cluj-Napoca that are discussed in detail here. In order to complete the picture, I have also discovered mentions of bezoars in other types written sources from that era. I shall present these sources in reverse order, starting with the general ones and ending with the particular apothecary artifacts.

At the beginning of the 17th century, Jesuit missionaries in Eastern Europe often wrote back to Rome to give reports of their work and asking for certain commodities, including bezoars (and theriac). In 1617 Brother Szini István wrote from Cluj, in the heart of Transylvania, asking for books, "belzuarro" (bezoar), theriac and other similar things against dangers that he feared [10, p. 280]. A couple of years earlier, in 1601, 1602, and 1604, Brother György Claudio Acquaviva, writing from present-day Slovakia, asked for a bezoar and explained that he did so because such items were lacking in Šala [11, p. 39, 145, 353]. The parallel is relevant as the request of the missionaries could have also been prompted by the lower price of such items if obtained through the Order's connections and not necessarily by the lack of bezoars in the local markets. Although research is scarce on the topic, it has been pointed out that Jesuit Colleges from South America were actively involved in shipping large quantities of bezoars to Rome [7, p. 20-21, footnote 50]. More than a century and a half later, in 1768, things had definitely changed, as Abbot Francois-Xavier de Feller 
wrote that "In Cluj I saw a beautiful bezoar brought from America, weighing one libra and two ounces. Here are some [bezoars] that weigh up to eight libras..." [12, p. 571]. One should note that at that time two characteristics were important in setting the value and significance of bezoars, i.e. their place of origin and their weight.

Another early mention seems to be to bezoar powder suspended in some liquid (water? wine?) administered as a last resort cure to a dying prince. In 1629 Prince of Transylvania, Gabriel Bethlen, fell ill and "doctors gave him bezoar to drink and he lived 24 more hours after that and faded from this world of shadows through a beautiful and calm death on November $26^{\text {th }} 1629 . "$ [13, p. 192]. It thus appears that the author of these diary lines, BurgerNagy Szabó Ferencz from Târgu Mureş believed that the cure was effective in that it granted a tranquil, i.e. "good death" to the ailing prince.

Other mid-17th to mid-18th century written sources also mention the ingredient. At the turn of the 18th century, Transylvania ceased to be an autonomous principality and became a province of the Habsburg Empire and this brought significant changes in the status of pharmacists and apothecary shops. The first had to pass formal examinations in order to practice and had to use official pharmacopoeias and dispensatories and the Viennese system of weights. Many apothecary shops became private; this meant their owners invested in marketing and retail in order to survive the competition with religious and state pharmacies, and there were more numerous inspections of such establishments [14, p. 3-4]. The written sources in question are apothecary tariff lists (Taxa Pharmaceutica) employed in Transylvania and inventories of apothecary shops performed during inspections or owner changes. "Bezoardicum" and "Bezoardicus" (short for "Lapis bezoardicus") feature as antidotes of animal origin in Justi Johannis Torkos' Taxa pharmaceutica Possoniensis (1745), a list of drug prices printed in Bratislava but used in Transylvania as well, in the Taxa pharmaceutica manuscript of Tobias Maucksch (1750) (a pharmacist who owned a private apothecary shop in Cluj and soon bought another in Târgu Mureș), and in the 1751 inventory of a pharmacy in Alba Iulia [9, p. 81]. In other cases the citations are more specific, and refer to "Bezoardicus occidentalis" and/or "Bezoardicus orientalis" [9, p. 101-102]. The first features in two inventories, that of the pharmacy in Alba Iulia in 1650 and the other tothe pharmacy in Târgu Mureş in 1790 and in two pharmaceutical taxes, that of Tobias Maucksch (1750) and Hutter-Soterius (1753). The second type, "Bezoardicus orientalis", features in the 1751 inventory of the pharmacy in Alba Iulia and in the two taxes mentioned above.

Both types of documents record the price or value of the items and they reflect the different pricing of the bezoars according to their type and rarity. The analysis of such issues from the era's sources must nevertheless be the topic of further research, as not all of these sources are fully edited and published and the intricate economic issues of monetary value and inflation in Transylvania during the Early Modern period render the interpretation more complex. Suffice it to say for now that some sources, such as the 1790 inventory of the apothecary shop from Târgu Mureş 


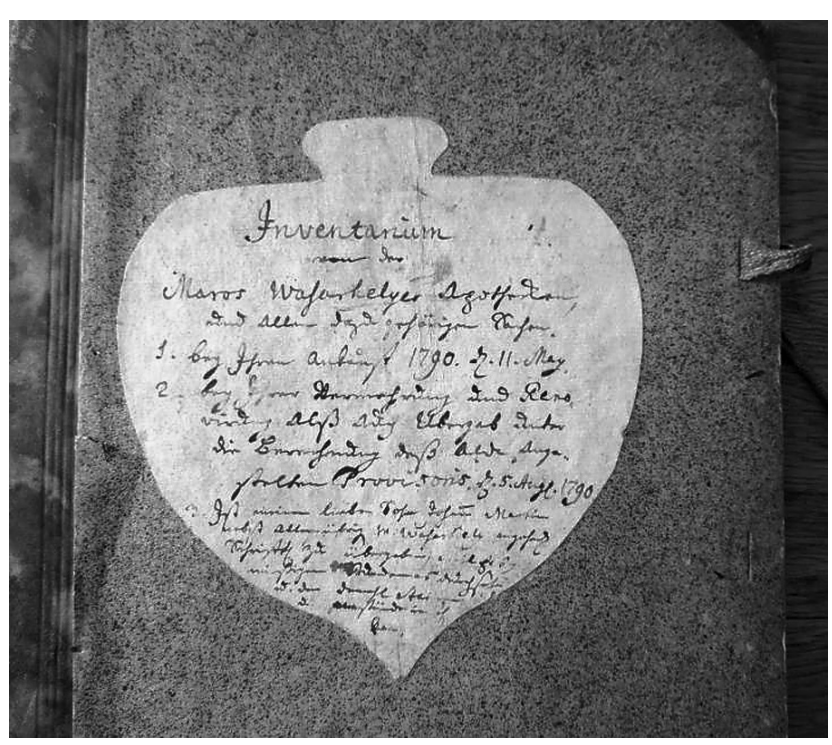

Fig. 1. Cover of the 1790 inventory of an apothecary shop from Târgu Mureș. Photo by the author.
(Fig. 1), preserved at the History of Pharmacy Collection in Cluj-Napoca (Inv. No. IF 2326) mentions three types, Oriental bezoar, Occidental bezoar, and Sennert's bezoar powder, confirming their parallel use (the source unfortunately does not record the quantity or price of all three). The first two types are listed under the category of "Materialia simplicia”, unprocessed ingredients, whilst also mentioning that the items in this lot were also called "exotica" and had been brought from Vienna (Fig. 2). The third

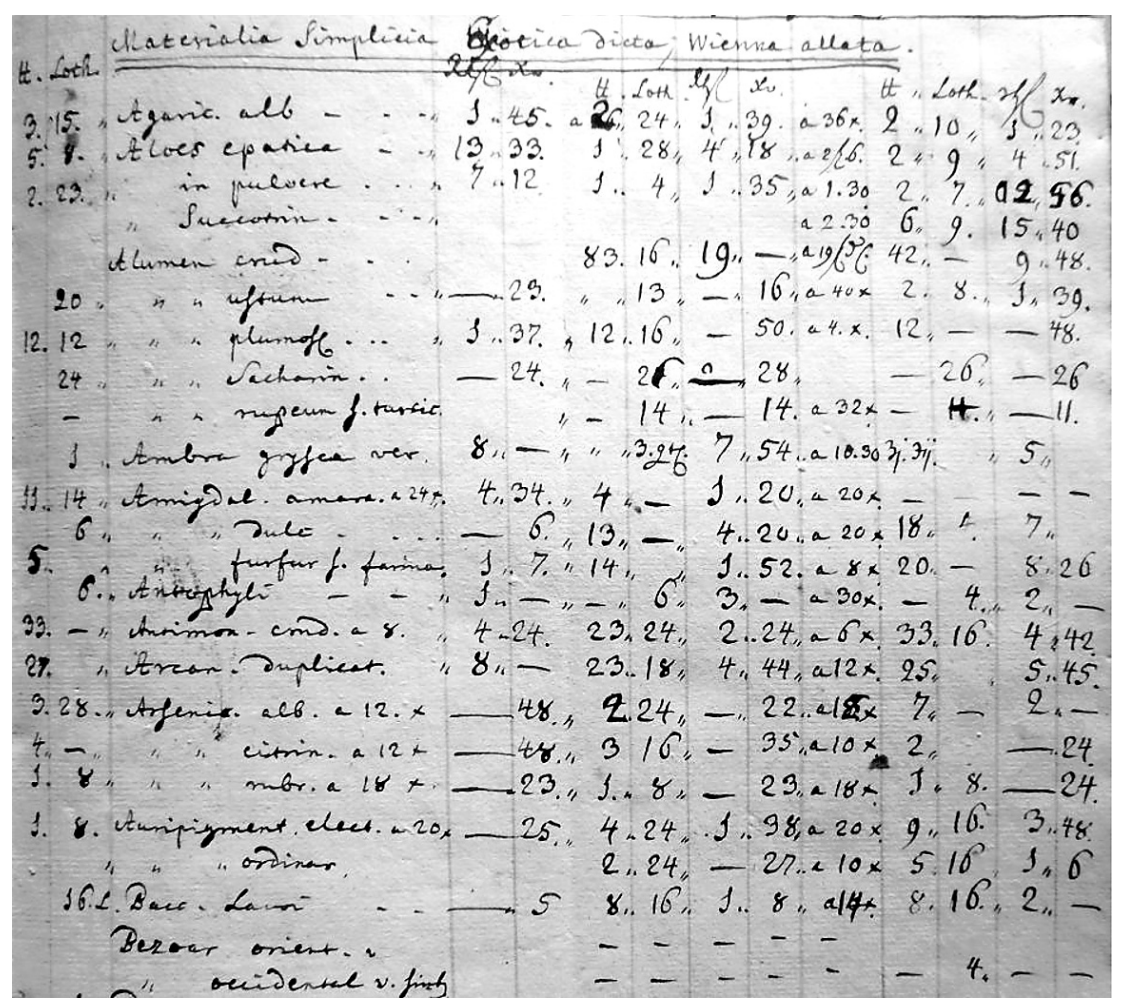

Fig. 2. Detail of the 1790 inventory of an apothecary shop from Târgu Mureş, fol. 1, with Oriental and Occidental bezoar listed. Photo by the author. 
type, Sennert's bezoar powder, is recorded under "Pulveres" and features in the 1792 completion of the inventory as well (Fig. 3).

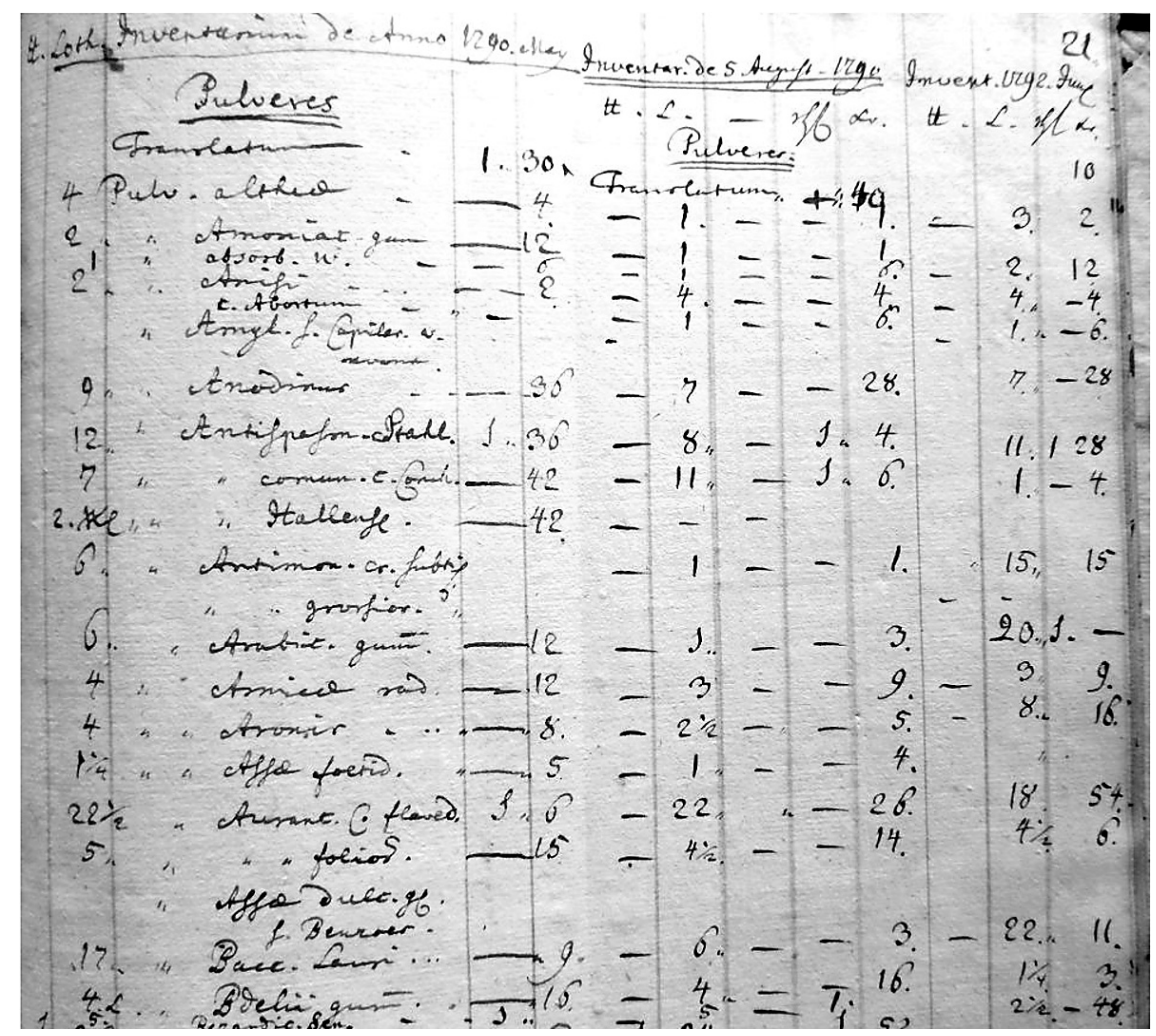

Fig. 3. Detail of the 1790 inventory of an apothecary shop from Târgu Mureş, fol. 21, with Sennert's bezoar powder listed. Photo by the author.

The History of Pharmacy Collection in Cluj-Napoca, part of the National History Museum of Transylvania, also includes 18th-century containers for bezoar powder. The three artifacts are part of an apothecary chest, owned by Tereza Keményi (Fig. 4). This portable pharmacy [Inv. No. IF 1903; 9, p. 253; 15, p. 14; 16, p. 82] has drawers with signatures for solid ingredients and 26 small glass jars for both powders and liquids with parchment or metal lids. The chest can be dated through a manuscript it contains in one of the drawers, a Specificatio (list of products, apparently of a lot sold to refresh the stock or to complete the contents of the chest) that contains the names of the owner, the pharmacist, and the date 1787. Among the jars, two are for bezoar powder (Fig. 5), as indicated by the manuscript inscriptions on the parchment lids: "Pulvis Bezoardie" (Inv. No. IF 1915) and "Pulvis Bezoardicus Sennerti" (Inv. No. IF 1916) (including the alchemical sign for powder, ). The denomination of the second type of bezoar is connected to the name of Daniel Sennert (1572-1637), a renowned German doctor interested in alchemy and (iatro)chemistry. He combined oriental bezoar powder with various other expensive ingredients (such as pearls, red 
coral, rubies, emeralds, crabs' eyes, deer heart etc.) in a cordial-type powder with various uses (against poison, plague, abortion, pox) that was also an ingredient of other mixed drugs [17, p. 6; 18, p. 246]. Sennert's Bezoar Powder is also recorded in the 1790 inventory of the apothecary shop from Târgu Mureş. Both jars still contain white-grayish powders and it would be interesting to have their composition analyzed in the future. One of the portable pharmacy's small drawers is also inscribed "Bezoard", denoting probably the storage inside it of a (small) stone or fragments of a bezoar (Fig. 6).

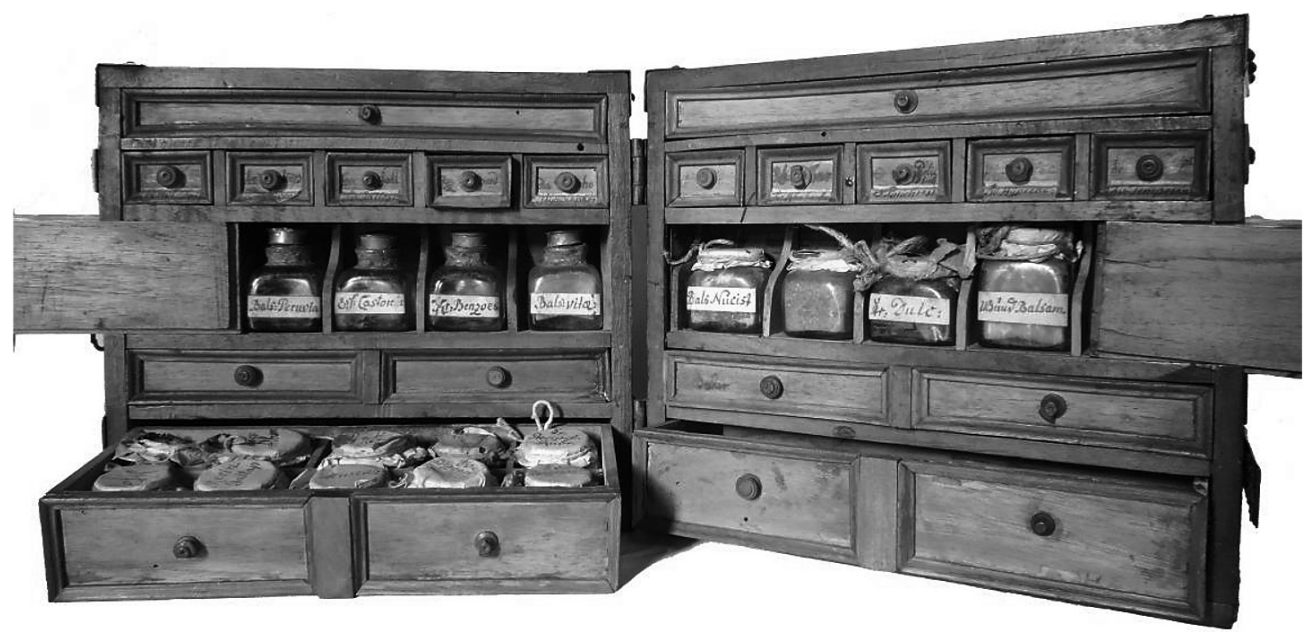

Fig. 4. Apothecary chest of noblewoman Tereza Keményi, around 1787. Photo by the author.

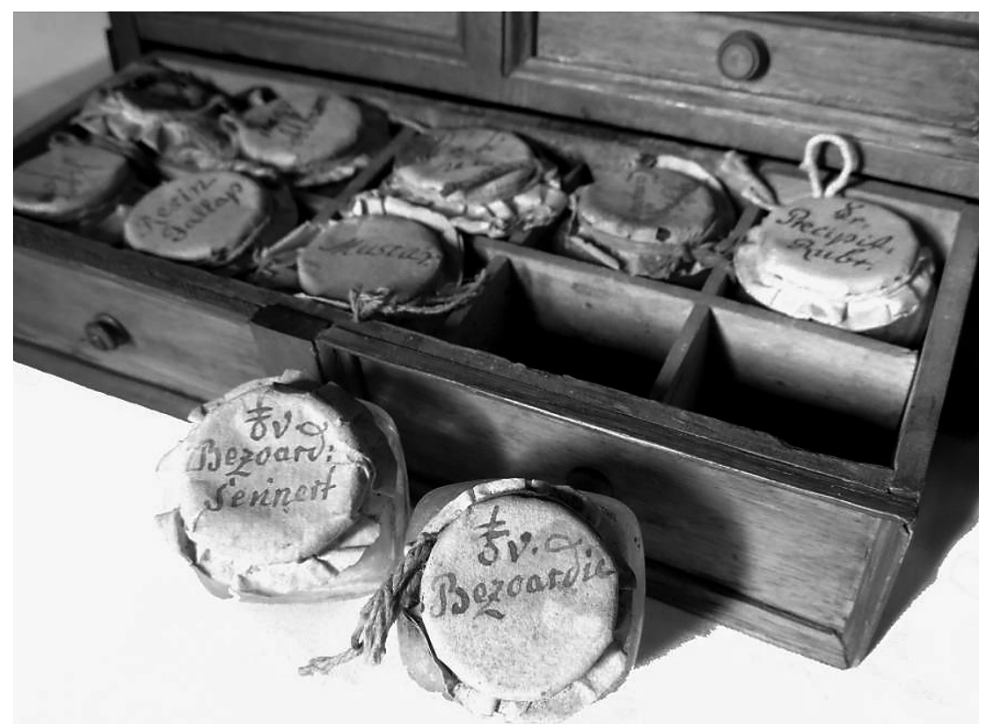

Fig. 5. Detail of Tereza Keményi's apothecary chest: apothecary jars for bezoar powder. Photo by the author. 


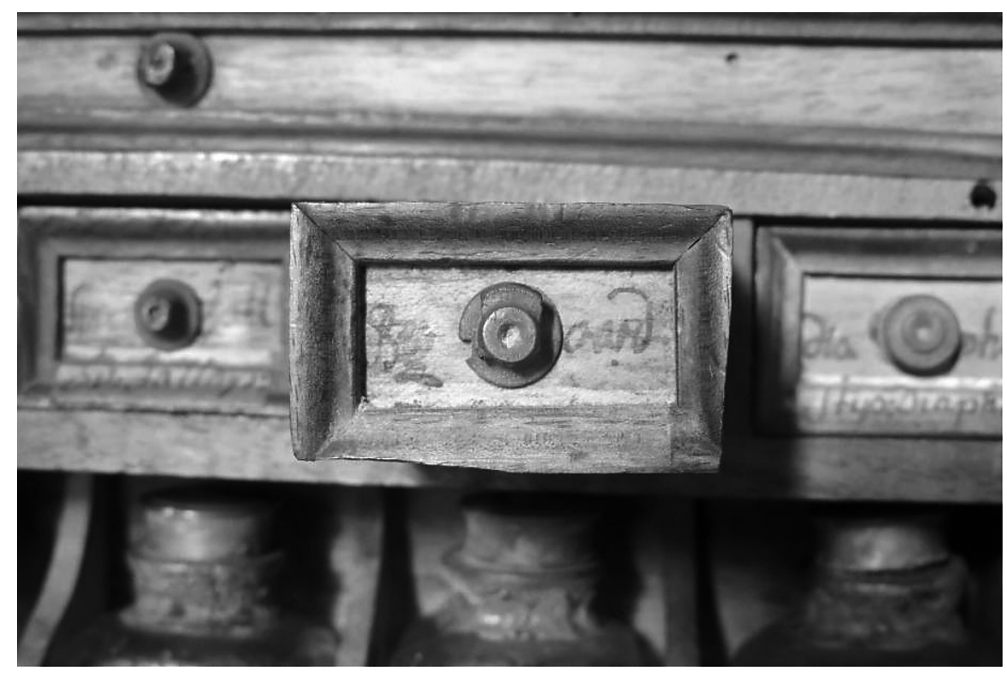

Fig. 6. Detail of Tereza Keményi's apothecary chest: small drawer inscribed "Bezoard". Photo by the author.

The presence of these ingredients in a portable pharmacy that a noble woman had with her while traveling or at home indicates that bezoar powder and stones were indeed considered useful in an emergency or when doctors and pharmacists were not around. Furthermore, the presence of three separate types (bezoar powder, Sennert's bezoar powder, and bezoar stone) indicates they were deemed essential and also that the owner of the chest was wealthy enough to afford such a variety of bezoar-related ingredients.

Eighteenth-century pharmacopoeias, inventories, and taxes are also rich in mentions of mineral bezoars (not of animal origin), such as: "Bezoardicum Minerale" (white antimony oxide) (inventories of the pharmacy in Alba Iulia compiled in 1751 and 1752; 9, p. 81), "Bezoardicum Solare" (antimony oxide and a little gold) (in the 1751 inventory of the pharmacy in Alba Iulia and in Tobias Maucksch's Taxa pharmaceutica of 1750; 9. p. 81), "Bezoardicum Joviale" (antimony oxide and lead oxide) (in the 1789 inventory of the pharmacy in Târgu Mureş and Tobias Maucksch's Taxa pharmaceutica of 1750; 9, p. 81), "Bezoardicum Lunare" (antimony oxide and silver chlorhydrate) (only in Tobias Maucksch's Taxa pharmaceutica of 1750; 9, p.81) and "Bezoardicum Martiale" (antimony oxide and iron oxide) (again only in Tobias Maucksch's Taxa pharmaceutica of 1750). The apothecary tax proposal includes five types of mineral bezoar, attesting to Tobias Maucksch's thoroughness or fondness for the products; 9 , p. 81 ). 


\section{Conclusions}

Early Modern Transylvanian Material medica was up-to-date in its inclusion of internationally used ingredients, including bezoar stones, although it seems that in Transylvania they became popular slightly later (during the 17th century rather than the 16th), and maintained their prestige and practical use a little longer, until the first part of the nineteenth century. Bezoars were used prophylactically and deemed essential by Jesuit missionaries in the principality at the beginning of the 17 th century. They wrote back to Rome asking for bezoars, noting their absence from the local markets. A case of princely bezoar use, as an (ineffective) last resort medicine, is recorded in 1629. The episode also shows the difficulties in interpreting or evaluating the efficacy of such cures - early modern Transylvanians did believe in the curative powers of bezoar stones even if they actually failed to cure and only granted a tranquil death. The first mentions of bezoars as apothecary ingredients are dated to the middle of the 17th century, though they became more numerous over the next 150 years. Several types are recorded in Transylvanian apothecary shops and taxes: oriental, occidental, Sennert's bezoar powder, and also mineral bezoars (not of animal origin). Bezoars were clearly very popular in the second half of the 18th century - beautiful South American stones could be admired by travelers in the cities of Transylvania (1768 in Cluj) and noblewomen carried them around in their apothecary chests (three types of them leaving little to chance - around 1787).

\section{Summary}

This represents a pioneering research on the use of bezoars in Transylvania during the $17^{\text {th }}$ and $18^{\text {th }}$ centuries. The author employs both written sources (correspondence, pharmacy inventories, apothecary taxes, and memoirs) and historical artifacts in order to reconstruct the place of bezoars in the era's Materia Medica, by comparison with Western Europe. Some of the written sources and all of the artifacts are preserved at the History of Pharmacy Collection in Cluj-Napoca of which the author is the main curator. The study aims to identify if, how and by whom bezoars and bezoar-related medicine were used in Transylvania and which of the exotic ingredient's varieties were accessible. The author's tentative conclusions are that bezoar stones became popular in Transylvania slightly later than in Western Europe, i.e. during the end of the $17^{\text {th }}$ and mainly in the $18^{\text {th }}$ century, that they were first used by Jesuits, princes and nobles, that their role was prophylactic, alexipharmic and as last resort medicine, and that the era's Materia Medica mentions several types: oriental, occidental, Sennert's bezoar powder, and also mineral bezoars (not of animal origin).

\section{List of illustrations}

1. Cover of the 1790 inventory of an apothecary shop from Târgu Mureş. Photo by the author.

2. Detail of the former, fol. 1, with Oriental and Occidental bezoars listed. Photo by the author.

3. Detail of the former, fol. 21, with Sennert's bezoar powder listed. Photo by the author. 
4. Apothecary chest of noblewoman Tereza Keményi, around 1787. Photo by the author.

5. Detail of the chest: apothecary jars for bezoar powder. Photo by the author.

6. Detail of the chest: small drawer inscribed "Bezoard". Photo by the author.

\section{References}

1. Barroso MDS. Bezoar Stones, Magic, Science, and Art. In: Duffin CJ, Moody RTJ, Gardner-Thorpe C, editors. A History of Geology and Medicine. London: Geological Society of London; 2013. p. 193-207.

2. Borschberg P. The Euro-Asian Trade in Bezoar Stones (approx. 1500 to 1700). In: North M, editor. Artistic and Cultural Exchanges between Europe and Asia 1400-1900, Farnham: Ashgate; 2010. p. 29-44.

3. Gambaccini P. Mountebanks and Medicasters. A History of Italian Charlatans from the Middle Ages to the Present. Jefferson: Mc.Farland; 2003.

4. Barroso MDS. The Bezoar Stone: a Princely Antidote, the Távora Sequeira Pinto u Oportu (Portugal). Acta med-hist Adriat. 2014; 12(1): 77-98.

5. Findlen P. Cabinets, Collecting, and Natural Philosophy. In: Fučícová E, Bradburne JM, Bukovinska B, Hausenblasova J, Konecny L, Muchka I et.al, editors. Rudolf II and Prague, Prague-London-Milan: Thames and Hudson; 1997. p.209-219.

6. Haag S, editor. Kunstkammer Vienna, Vienna: Kunst Historisches Museum; 2013.

7. Stephenson M. From Marvelous Antidote to the Poison of Idolatry: The Transatlantic Role of Andean Bezoar Stones during the Late 16th and Early 17th Centuries. Hisp Am Hist Rev. 2010; 90:1: 3-39.

8. Gruia AM. Harry Potter și adevărata istorie a farmaciei [Harry Potter and the Real History of Pharmacy]. Cluj-Napoca: Mega; 2015.

9. Crișan E. Materia Medica de Transylvanie. Cluj-Napoca: Muzeul Național de Istorie a Transilvaniei, 1996.

10. Balázs M, Fricsy Á, Lukács L, Monok I, editors. Erdélyi és hódoltsági jezsuita missziók: 1/2., 1617-1625 [Jesuit Missions in Transylvania and in Ottoman Hungary]. Szeged: Scriptum; 1990.

11. Balázs M, Kruppa T, Lázár ID, Lukács L, editors. Jezsuita okmánytár: Erdélyt és Magyarországot érintő iratok, 1601-1606. [Jesuit Diplomatics: Documents Concerning Transylvania and Hungary, 1601-1606]. Szeged: JATE; 1995.

12. Hoban M, redactor. Călători străini despre țările române [Foreign Travelers on the Romanian Countries], vol. IX. București: Ed. Academiei Române; 1997.

13. Gall Mihăilescu Ş, translator. Memorialul lui Nagy Szabó Ferencz din Târgu Mureş (15801658) [The Memorial of Nagy Szabó Ferencz from Târgu Mureş (1580-1658)]. Bucureşti: Kriterion; 1993.

14. Gruia AM. Apothecary aphrodisiac drinks in 18th-century Transylvania. Brukenthal. Acta Musei. 2016 May.

15. Nékám L. Old Hungarian Pharmacies, Budapest: Korvina; 1968.

16. Orient G. Az erdélyi és bánáti gyógyszerészet története, Kolozsvár: Minerva; 1926. 
17. D.S.A.F. Pest-Buch Oder Auszug der herrlichst- und aller-bewährtesten Pest-Mitteln (...), Nürnberg: Rüdiger, 1713.

18. Cartheuser JF. Pharmacologia theoretico-practica rationi et experientiae superstructa (...), Venetiis: Dominicus Deregni, 1756.

Submitted: 15. 9. 2016.

Reviewed: 12. 10. 2016.

Accepted: 24. 10. 2016. 